\title{
SIFAT FISIKA DAN MEKANIKA KAYU JATI UNGGUL "MEGA" DAN KAYU JATI KONVENSIONAL YANG DITANAM DI HUTAN PENDIDIKAN WANAGAMA, GUNUNGKIDUL, YOGYAKARTA
}

\section{FANNY HIDAYATI ${ }^{*}$, ISTI TAMIRA FAJRIN ${ }^{1}$, MUHAMMAD ROSYID RIDHO ${ }^{1}$, WIDYANTO DWI NUGROHO ${ }^{1}$, SRI NUGROHO MARSOEM ${ }^{1}$, \& MOHAMMAD NA' IEM $^{2}$}

${ }^{1}$ Departemen Teknologi Hasil Hutan, Fakultas Kehutanan, Universitas Gadjah Mada

${ }^{2}$ Departemen Silvikultur, Fakultas Kehutanan, Universitas Gadjah Mada

Jl. Agro No. 1, Bulaksumur, Sleman, 55281

*Email: fanny_hidayati@ugm.ac.id

\begin{abstract}
Demand of teak wood increases every year along the increase of human population and prosperity. On the other hand, teak is one of the long rotation tree species. Furthermore, the avaibility of teak from the Perum Perhutani as the biggest teak plantation company is not enough to fulfill the demand of teak wood from wood industry. Therefore, many efforts have been conducted to solve this problem, such as by tree breeding program. In Indonesia, this program only focused in the growth characteristics. However, information of wood properties of superior teak is still limited in Indonesia. Therefore, the aim of this research was to clarify the physical and mechanical characteristics of superior teak wood (11-year-old) and compared with the conventional teak (14-year-old) planted in Wanagama Forest, Gunungkidul, Yogyakarta and its longitudinal variation. As the results, physical properties were not significantly different between superior teak and conventional teak, except for green moisture content. Bending strength (MOR dan MOE) and compression strength parallel to grain were significantly different between superior and conventional teak. In addition, compressive strength perpendicular to grain was not significantly different between superior and conventional teak.
\end{abstract}

Keywords: superior teak, conventional teak, physical properties, mechanical properties, young tree age.

\section{INTISARI}

Kebutuhan kayu jati semakin meningkat dari tahun ke tahun seiring dengan peningkatan jumlah penduduk dan taraf hidup masyarakat. Di lain pihak, jati merupakan salah satu jenis dengan rotasi umur yang panjang. Selain itu, ketersediaan kayu jati dari Perum Perhutani belum mampu memenuhi kebutuhan kayu jati untuk industri. Oleh sebab itu, berbagai upaya telah dilakukan untuk mengatasi masalah ini. Salah satunya adalah dengan kegiatan pemuliaan pohon, dimana dalam kegiatan ini dihasilkan bibit unggul dengan sifat pertumbuhan superior. Akan tetapi, informasi mengenai sifat-sifat kayunya masih sangat terbatas, sehingga penelitian ini bertujuan untuk memberikan informasi mengenai sifat-sifat kayu terutama sifat fisika (kadar air, berat jenis, dan penyusutan) dan mekanika (kekuatan lengkung statis dan kekuatan tekan) serta variasi aksial kayu jati unggul tersebut pada umur yang masih muda yakni 11 tahun yang ditanam di Hutan Pendidikan Wanagama, Gunungkidul Yogyakarta dan dibandingkan dengan jati konvensional umur 14 tahun yang ditanam di lokasi yang sama. Sebagai hasilnya, sifat fisika kayu tidak berbeda nyata antara kayu jati unggul dan kayu jati konvensional, kecuali kadar air segar. Untuk sifat mekanika kayu, kekuatan lengkung statis (MOR dan MOE) serta kekuatan tekan sejajar serat berbeda nyata antara kayu jati unggul dan jati konvensional, sedangkan untuk kekuatan tekan sejajar serat tidak berbeda nyata.

Kata kunci: jati unggul, jati konvensional, sifat fisika, sifat mekanika, umur muda. 


\section{PENDAHULUAN}

Kayu jati merupakan salah satu jenis kayu tropis yang sangat penting karena reputasinya sebagai kayu berkualitas tinggi. Masyarakat memilih kayu jati karena penampilannya yang menarik, kuat, memiliki keawetan alami yang tinggi serta pengerjaannya yang mudah. Dari tahun ke tahun permintaan kayu jati meningkat sekitar $13-17 \%$ per tahun seiring dengan bertambahnya jumlah penduduk serta kenaikan taraf hidup masyarakat (Mawardi, 2012). Di lain pihak, jati merupakan salah satu jenis pohon yang memiliki rotasi panjang serta produksinya cenderung menurun dari tahun ke tahun. Total permintaan kayu jati di Indonesia kira-kira 1,5-2,2 juta $\mathrm{m}^{3}$ (Rodha et al., 2007). Pada tahun 2012, Perum Perhutani sebagai penghasil kayu jati terbesar di Indonesia menghasilkan $403.432 \mathrm{~m}^{3}$ (Perum Perhutani, 2012). Adapun kekurangannya dipenuhi oleh kayu jati dari hutan rakyat serta jenis-jenis kayu rakyat lainya. Dari kondisi tersebut, maka terjadi ketidakseimbangan antara permintaan dan ketersediaan kayu jati.

Berbagai usaha telah dilakukan untuk mengatasi masalah tersebut, antara lain dengan menurunkan umur daur, memanfaatkan hasil tebangan penjarangan, serta pemuliaan pohon untuk memperoleh bibit unggul. Kegiatan pemuliaan pohon ini salah satunya adalah bagaimana menghasilkan pohon jati dengan sifat pertumbuhan yang superior sehingga diharapkan dapat menurunkan umur daur. Salah satunya yaitu uji coba klon yang diperoleh dari seleksi lebih dari 600 pohon induk. Dari hasil uji coba klon-klon yang dilakukan di beberapa lokasi (Cepu, Ciamis, Ngawi, dll.) diperoleh beberapa klon dengan sifat-sifat pertumbuhan terbaik (Na'iem 2000; Wardani et al., 2008). Selain itu 2 klon terbaik diujicobakan ditanam di Hutan Pendidikan Wanagama, Gunungkidul, Yogyakarta pada tahun 2004.
Pohon dari klon-klon ini memiliki sifat-sifat pertumbuhan yang superior (diameter, tinggi, pohon, serta kelurusan batang).

Penelitian mengenai kualitas kayu jati sudah banyak dilakukan baik di Indonesia maupun di luar negeri (Kedharnath et al., 1963; Putro dan Sutjipto, 1989; Sulistyo dan Marsoem, 1995; Indira dan Bhat, 1998; Bhat et al., 2001; Cordero dan Kanninen, 2003; Bhat dan Priya, 2004; Wahyudi dan Arifien, 2005; Krisdianto dan Sumarni, 2006; Moya dan Marin, 2011; Basri dan Wahyudi, 2012; Wahyudi et al., 2014a, 2014b; Hidayati et al., 2013a, 2013b; Hidayati et al., 2014). Di Indonesia penelitian mengenai sifat-sifat kayu jati unggul masih relatif terbatas (Wahyudi dan Arifien, 2005; Krisdianto dan Sumarni, 2006; Hidayati dan Marsoem, 2010; Basri dan Wahyudi, 2012; Wahyudi et al., 2014a, 2014b). Oleh karena itu, penelitian ini bertujuan untuk mengetahui sifat fisika dan mekanika kayu jati unggul serta perbandingannya dengan kayu jati konvensional pada umur muda sehingga diharapkan dapat diperoleh informasi yang lebih lengkap mengenai sifat-sifat kayu jati unggul dan variasi aksial sifat-sifat tersebut.

\section{BAHAN DAN METODE}

Bahan yang digunakan dalam penelitian ini adalah tiga batang pohon jati unggul "Mega" (klon) dan tiga pohon jati konvensional (biji). Pohon jati unggul berumur 11 tahun, sedangkan jati konvensional berumur 14 tahun. Pohon-pohon sampel yang digunakan ini berasal dari Hutan Pendidikan Wanagama, Gunungkidul, Yogyakarta. Tahap pertama dalam pelaksanaan penelitian adalah membuat petak ukur $20 \mathrm{~cm} \times 20 \mathrm{~cm}$ pada lokasi uji jati unggul dan jati konvensional. Selanjutnya diukur diameter setinggi dada pada semua pohon dalam petak tersebut. Dari data diameter tersebut kemudian 
dicari rata-ratanya. Setelah memperoleh nilai rata-rata, dipilih 3 buah pohon dengan diameter pada kisaran nilai rata-rata tersebut. Tabel 1 menunjukkan diameter dan tinggi pohon sampel.

Selanjutnya keenam pohon tersebut ditebang kemudian diukur panjangnya (sebagai tinggi pohon). Pada pohon yang telah rebah, batang dibagi tiap panjang $2 \mathrm{~m}$. Dari tiap-tiap bagian batang tersebut diuji sifat fisika dan mekanikanya. Untuk pengambilan sampel pada arah radial dilakukan dengan cara membagi permukaan kayu (bidang tranversal) setiap $2 \mathrm{~cm}$ dari hati ke kulit pada masing-masing bagian batang pada 2 arah yang berlawanan. Selanjutnya, nilai yang diperoleh dirata-rata. Pengambilan sampel uji sifat mekanika kayu pada arah radial dilakukan dengan cara membagi permukaan kayu (bidang transversal) setiap $2 \mathrm{~cm}$ dari hati ke kulit pada masing-masing bagian batang pada 1 arah. Data radial dari setiap sampel dirata-rata sehingga diperoleh data per $2 \mathrm{~m}$. Data ini kemudian digunakan untuk mengetahui variasi aksial sifat-sifat kayunya. Pengujian sifat fisika dan mekanika kayu mengacu pada British Standard 373 tahun 1957. Selanjutnya, dalam penelitian ini, data dianalisis menggunakan $\mathrm{t}$-test untuk membandingkan kayu jati unggul dan konvensional. Analisis tersebut dilakukan dengan menggunakan software Excel.

\section{HASIL DAN PEMBAHASAN}

Tabel 2 menunjukkan nilai rata-rata sifat fisika kayu jati unggul dan kayu jati konvensional. Nilai rata-rata kadar air segar kayu jati unggul dan kayu konvensional adalah 109\% dan 95\%, secara berurutan. Sulistyo dan Marsoem (1995) melaporkan bahwa kadar air segar kayu jati konvensional yang ditanam di KPH Madiun pada kelas umur IV, VI, dan VII adalah 94,79\%; 82,42\%; dan 44,90\%, secara berurutan. Pada penelitian ini, kadar air segar untuk jati unggul lebih besar dari hasil penelitian sebelumnya. Pada evaluasi tahap 1 (umur 5 tahun), diperoleh bahwa proporsi sel pembuluh lebih besar dibandingkan dengan kayu jati konvensional dari hutan rakyat (Hidayati dan Marsoem, 2010). Sifat anatomi ini dimungkinkan menjadi penyebab kadar air kayu jati unggul lebih tinggi secara signifikan dibanding kayu jati konvensional. Pada jati konvensional menunjukkan hasil dalam kisaran yang sama pada kelas umur IV (Sulistyo dan Marsoem, 1995). Namun, apabila dilihat pada kelas umur yang lebih tua menunjukkan bahwa kadar air segar menurun seiring dengan semakin tuanya umur kayu (Sulistyo dan Marsoem, 1995). Selanjutnya, kadar air segar berbeda nyata antara jati unggul dan jati konvensional, dimana jati unggul memiliki kadar air segar yang lebih tinggi

Tabel 1. Diameter dan tinggi pohon sampel

\begin{tabular}{lccc}
\hline Jenis sumber benih & Ulangan & Diameter $(\mathrm{cm})$ & Tinggi $(\mathrm{m})$ \\
\hline Jati unggul & 1 & 21,3 & 17,8 \\
(klon) & 2 & 20,3 & 17,3 \\
& 3 & 20,1 & 14,3 \\
& Rata-rata & 20,6 & 16,5 \\
& SD & 0,6 & 1,9 \\
Jati konvensional & 1 & 14,8 & 14,9 \\
(biji) & 2 & 15,1 & 13,1 \\
& 3 & 14,4 & 12,0 \\
& Rata-rata & 14,8 & 13,3 \\
& SD & 0,4 & 1,5 \\
\hline
\end{tabular}

Ket: $\mathrm{SD}=$ Standar deviasi 
(Tabel 2). Hasil ini dimungkinkan terkait dengan beberapa sifat lainnya seperti anatomi dan kimia (ekstraktif) kayunya, sehingga penelitian lebih lanjut mengenai sifat anatomi dan sifat kimianya sangat diperlukan untuk memahaminya.

Nilai rata-rata berat jenis kayu jati unggul dan jati konvensional adalah 0,50 dan 0,55 , secara berturutan (Tabel 2). Basri dan Wahyudi (2012) melaporkan bahwa berat jenis kayu jati unggul (JPP) dari Jawa Tengah pada umur 5, 7, dan 9 tahun adalah 0,46, 0,49 , dan 0,51 , secara berturutan. Selanjutnya berat jenis kayu jati superior pada umur 3 tahun yang ditanam di Semarang adalah 0,43-0,64 (Wahyudi dan Arifien, 2005). Wahyudi et al. (2014a) juga melaporkan bahwa berat jenis kayu jati superior pada umur 4 dan 5 tahun yang ditanam di Jawa Barat adalah 0,35 dan 0,45 , secara berturut-turut. Wanneng et al. (2014) menemukan bahwa kerapatan dasar pada umur 10,15, 20, dan 25 tahun pada jati yang ditanama di Laos adalah $0,53 \mathrm{~g} / \mathrm{cm}^{3}, 0,52 \mathrm{~g} / \mathrm{cm}^{3}, 0,53$ $\mathrm{g} / \mathrm{cm}^{3}$, dan $0,50 \mathrm{~g} / \mathrm{cm}^{3}$, secara berurutan. Berat jenis kayu jati konvensional pada umur 8 tahun yang ditanam di Semarang adalah 0,47-0,70 (Wahyudi dan Arifien, 2005). Di Pulau Solomon, kerapatan dasar pohon jati umur 10 tahun adalah $0,54 \mathrm{~g} / \mathrm{cm}^{3}$ (Anonim, 2011). Sulistyo dan Marsoem (1995) melaporkan bahwa berat jenis berdasarkan volume kering angin pada kelas umur IV, VI, dan VII adalah 0,$68 ; 0,57$; dan 0,60, secara berurutan. Pada umur 7,
17, dan 27 tahun berat jenis berdasarkan volume kering angin adalah 0,57 ; 0,62; dan 0,64 (Putro dan Sutjipto, 1989). Suwarno et al. (2000) melaporkan bahwa berat jenis kering udara pohon jati dari biji pada umur 15 tahun adalah 0,55 . Pada penelitian ini, nilai rata-rata berat jenis kayu jati unggul dan kayu jati konvensional berada dalam kisaran hasil penelitian terdahulu (Basri dan Wahyudi 2012; Wanneng et al., 2014; Wahyudi dan Arifien, 2005). Selain itu bila dikaitkan dengan penelitian terdahulu menunjukkan bahwa seiring pertambahan umur pohon maka berat jenis akan naik, namun pada umur 60 tahun mulai menurun. Selanjutnya, berdasarkan hasil uji statistik menggunakan t-test menunjukkan bahwa berat jenis tidak berbeda nyata antara kayu jati unggul dan kayu jati konvensional (Tabel 2). Wahyudi dan Arifien (2005) melaporkan bahwa pada umur 3 tahun, kayu jati unggul dan kayu jati konvensional tidak berbeda secara nyata. Hasil penelitian ini seiring dengan hasil penelitian tersebut.

Nilai rata-rata penyusutan pada arah radial, tangensial, dan longitudinal ditunjukkan pada Tabel 2. Nilai rata-rata penyusutan radial, tangensial, dan longitudinal adalah 4,6\% dan 5,4\%; 7,9\% dan 8,5\%; serta $1,0 \%$ dan $1,0 \%$ untuk kayu jati unggul dan konvensional secara berurutan. Putro dan Sutjipto (1989) melaporkan bahwa penyusutan radial untuk kayu jati umur 7, 17, dan 27 tahun adalah 1,97\%; $2,19 \%$; dan 2,42\%. Untuk penyusutan tangensial

Tabel 2. Sifat fisika kayu jati unggul dan konvensional

\begin{tabular}{lccccc}
\hline \multirow{2}{*}{ Sifat fisika } & \multicolumn{2}{c}{ Klon } & \multicolumn{2}{c}{ Biji } & T-test antara jati unggul dengan \\
\cline { 2 - 5 } jati konvensional (P-value)
\end{tabular}

Ket: $\mathrm{R}=$ radial, $\mathrm{T}=$ tangensial, $\mathrm{L}=$ longitudinal, $\mathrm{SD}=$ standar deviasi, $*$ =berbeda nyata pada taraf uji $5 \%$, $\mathrm{ns}=$ tidak berbeda nyata 
adalah 3,00\%; 3,55\%; dan 4,07\%. Suwarno et al. (2000) melaporkan bahwa penyusutan radial dan tangensial pada pohon jati dari biji umur 15 tahun adalah 2,02\% dan 3,08\%. Di lain pihak, penyusutan radial kayu jati pada kelas umur IV, VI, dan VII adalah $3,13 \% ; \quad 2,3 \%$; dan $2,1 \%$. Penyusutan tangensialnya adalah $5,57 \% ; 4,01 \%$; dan $3,59 \%$ sedangkan untuk penyusutan longitudinalnya adalah 0,33\%; 0,41\%; dan 0,36\% (Sulistyo dan Marsoem, 1995). Pada penelitian ini nilai penyusutan radial, tangensial, dan longitudinal lebih tinggi dibandingkan dengan hasil pada penelitian sebelumnya (Putro dan Sutjipto, 1989; Suwarno et al., 2000). Meskipun demikian, penyusutan radial, tangensial, dan longitudinal tidak berbeda nyata antara jati unggul dan konvensional (Tabel 2).

Nilai rata-rata rasio T/R disajikan pada Tabel 2. Nilai rata-rata T/R untuk jati unggul dan konvensional adalah 1,7 dan 1,6. Wahyudi et al. (2014a) melaporkan bahwa nilai T/R pada kayu jati unggul umur 4 dan 5 tahun adalah 3,02 dan 2,67. Pada penelitian ini nilai $\mathrm{T} / \mathrm{R}$ lebih rendah dibandingkan dengan hasil tersebut. Hal ini menunjukkan bahwa, meskipun penyusutan radial dan tangensial cukup besar pada kayu jati unggul dan jati konvensional pada penelitian ini, namun dimensi kayunya cukup stabil yang ditunjukkan oleh nilai T/R. Selanjutnya, T/R tidak berbeda nyata antara jati unggul dan jati konvensional (Tabel 2). Dari hasil ini dapat diperkirakan bahwa kayu jati unggul dan kayu jati konvensional memiliki kestabilan dimensi yang sama.

Tabel 3 menunjukkan nilai rata-rata sifat mekanika kayu jati unggul dan kayu jati konvensional. Nilai rata-rata kekuatan lengkung statis kayu jati unggul dan konvensional untuk MOR adalah 739 $\mathrm{kg} / \mathrm{cm}^{2}$ dan $941 \mathrm{~kg} / \mathrm{cm}^{2}$, sedangkan nilai rata-rata MOE adalah $90.000 \mathrm{~kg} / \mathrm{cm}^{2}$ dan $108.000 \mathrm{~kg} / \mathrm{cm}^{2}$.
MOR dan MOE pada jati umur 10 tahun yang tumbuh di Pulau Solomon adalah $1.080 \mathrm{~kg} / \mathrm{cm}^{2}$ dan $118.000 \mathrm{~kg} / \mathrm{cm}^{2}$ (Anonim, 2011). Wahyudi dan Arifien (2005) melaporkan bahwa MOR dan MOE pada jati konvensional umur 8 tahun yang ditanam di Semarang adalah sekitar $970 \mathrm{~kg} / \mathrm{cm}^{2}$ dan 73.000 $\mathrm{kg} / \mathrm{cm}^{2}$. Di lain pihak, MOR pada umur 3 tahun untuk jati unggul dan konvensional adalah $780 \mathrm{~kg} / \mathrm{cm}^{2}$ dan $720 \mathrm{~kg} / \mathrm{cm}^{2}$, sedangkan MOE sebesar $62.000 \mathrm{~kg} / \mathrm{cm}^{2}$ dan $42.000 \mathrm{~kg} / \mathrm{cm}^{2}$ (Wahyudi dan Arifien, 2005). Selanjutnya, MOR pada umur 4 dan 5 tahun untuk kayu jati unggul adalah $654 \mathrm{~kg} / \mathrm{cm}^{2}$ dan $782 \mathrm{~kg} / \mathrm{cm}^{2}$. Pada umur yang sama, MOE sebesar $77.995 \mathrm{~kg} / \mathrm{cm}^{2}$ dan $80.653 \mathrm{~kg} / \mathrm{cm}^{2}$ (Wahyudi et al., 2014a). Putro dan Sutjipto (1989) melaporkan bahwa MOR pohon jati umur 7, 17, dan 27 tahun adalah 690,98 kg/ $\mathrm{cm}^{2}$, $762,01 \mathrm{~kg} / \mathrm{cm}^{2}$, dan $884,07 \mathrm{~kg} / \mathrm{cm}^{2}$; sedangkan untuk MOE adalah $96.040 \mathrm{~kg} / \mathrm{cm}^{2}, 107.290 \mathrm{~kg} / \mathrm{cm}^{2}$, dan $121.380 \mathrm{~kg} / \mathrm{cm}^{2}$, secara berurutan. Suwarno et al. (2000) menambahkan bahwa MOR dan MOE pohon jati umur 15 tahun yang berasal dari biji adalah $946,21 \mathrm{~kg} / \mathrm{cm}^{2}$ dan $87.560 \mathrm{~kg} / \mathrm{cm}^{2}$. Pada penelitian ini nilai MOR jati unggul dan jati konvensional masuk dalam kisaran hasil penelitian terdahulu (Wahyudi et al., 2014a; Putro dan Sutjipto, 1989; Suwarno et al., 2000).

Selanjutnya, nilai MOE pada penelitian ini lebih tinggi dibanding dengan penelitian sebelumnya pada umur yang lebih muda (Wahyudi dan Arifien, 2005; Wahyudi et al., 2014a), namun dalam kisaran nilai sebelumnya (Putro dan Sutjipto, 1989; Suwarno et al., 2000; Anonim, 2011). Selanjutnya, berdasarkan uji t-test pada Tabel 3 menunjukkan bahwa MOR dan MOE berbeda nyata antara jati unggul dan jati konvensional, dimana jati konvensional memiliki nilai yang lebih tinggi. Hal ini bisa dihubungkan dengan berat jenisnya dimana berat jenis kayu jati konvensional lebih tinggi dibanding jati unggul 
meskipun tidak berbeda secara signifikan (Tabel 2). Selanjutnya, semakin tua umur pohon dimungkinkan semakin tinggi pula sifat mekanika kayunya.

Kekuatan tekan sejajar dan tegak lurus serat juga diuji pada penelitian ini. Nilai rata-rata kekuatan tekan sejajar serat untuk kayu jati unggul dan konvensional adalah $433 \mathrm{~kg} / \mathrm{cm}^{2}$ dan $497 \mathrm{~kg} / \mathrm{cm}^{2}$ (Tabel 3). Untuk kekuatan tekan tegak lurus serat adalah $203 \mathrm{~kg} / \mathrm{cm}^{2}$ dan $106 \mathrm{~kg} / \mathrm{cm}^{2}$. Putro dan Sutjipto (1989) melaporkan bahwa kekuatan tekan sejajar serat pada jati umur 7, 17, dan 27 tahun adalah $368 \mathrm{~kg} / \mathrm{cm}^{2}, 438 \mathrm{~kg} / \mathrm{cm}^{2}$, dan $497 \mathrm{~kg} / \mathrm{cm}^{2}$, secara berurutan. Pada umur 15 tahun, kekuatan tekan sejajar serat kayu jati konvensional adalah 464 $\mathrm{kg} / \mathrm{cm}^{2}$ (Suwarno et al., 2000). Pada penelitian ini, kekuatan tekan sejajar serat kayu jati unggul dan konvensional masuk dalam kisaran penelitian sebelumnya (Putro dan Sutjipto, 1989; Suwarno et al., 2000). Informasi kekuatan tekan tegak lurus serat pada kayu jati muda relatif jarang. Di lain pihak, pada kelas umur IV, VI, dan VII, kekuatan tekan tegak lurus serat adalah $232 \mathrm{~kg} / \mathrm{cm}^{2}, 162 \mathrm{~kg} / \mathrm{cm}^{2}$, dan 210 $\mathrm{kg} / \mathrm{cm}^{2}$. Pada penelitian nilai kekuatan tegak lurus serat untuk kayu jati unggul sebanding dengan hasil penelitian sebelumnya pada umur yang lebih tua, sedangkan untuk jati konvensional lebih rendah (Sulistyo dan Marsoem, 1995). Selanjutnya, kekuatan tekan sejajar serat berbeda nyata antara jati unggul dan jati konvensional, sedangkan kekuatan tekan tegak lurus serat tidak berbeda nyata (Tabel 3).
Seperti halnya pada kekuatan lengkung statis, hal ini terkait dengan berat jenis yang lebih tinggi pada kayu jati konvensional serta dimungkinkan bahwa sifat anatomi ataupun sifat kimia juga dapat berpengaruh. Sebagai tambahan, berdasarkan berat jenis, MOR, dan kekuatan tekan sejajar serat, maka kayu jati unggul dan kayu jati konvensional ini berada pada kisaran kelas kuat 2 dan 3. Hal ini disebabkan untuk berat jenis masuk ke dalam kategori kelas kuat 3, sedangkan untuk MOR dan kekuatan tekan sejajar serat masuk pada kelas kuat 2 (Anonim, 1976).

Gambar 1, 2, 3, dan 4 menunjukkan variasi aksial sifat fisika dan mekanika kayu jati unggul dan jati konvensional. Variasi aksial kadar air segar naik dari pangkal sampai dengan 2-4 $\mathrm{m}$ di atas tanah kemudian sedikit turun sampai ke ujung (Gambar 1). Seiring dengan hal tersebut, berat jenis segar turun dari pangkal sampai dengan 2-4 m (Gambar 1). Secara umum, diketahui bahwa berat jenis berkorelasi negatif terhadap kadar air (Bowyer et al., 2003). Variasi penyusutan radial dan longitudinal menunjukkan nilai yang berfluktuasi sedikit sampai dengan ketinggian $6 \mathrm{~m}$ di atas tanah (Gambar 2). Selanjutnya, untuk penyusutan radial mulai naik sedangkan penyusutan tangensial berfluktuasi agak menurun (Gambar 2). Penyusutan longitudinal memiliki pola yang berfluktuasi besar dari pangkal ke ujung (Gambar 2). MOR dan MOE memiliki pola variasi aksial yang hampir sama yakni berfluktuasi dari pangkal ke ujung (Gambar 3). Selanjutnya,

Tabel 3. Sifat mekanika kayu jati unggul dan konvensional

\begin{tabular}{|c|c|c|c|c|c|}
\hline \multirow{2}{*}{ Sifat mekanika } & \multicolumn{2}{|c|}{ Klon } & \multicolumn{2}{|c|}{ Biji } & \multirow{2}{*}{$\begin{array}{l}\text { T-test antara jati unggul dengan } \\
\text { jati konvensional (P-value) }\end{array}$} \\
\hline & Rata-rata & SD & Rata-rata & SD & \\
\hline Kekuatan lengkung statis & & & & & \\
\hline $\operatorname{MOR}\left(\mathrm{kg} / \mathrm{cm}^{2}\right)$ & 736 & 26 & 941 & 80 & $0.03 *$ \\
\hline $\operatorname{MOE}\left(\mathrm{x} 1000 \mathrm{~kg} / \mathrm{cm}^{2}\right)$ & 90 & 9 & 108 & 11 & $0.02 *$ \\
\hline Kekuatan tekan & & & & & \\
\hline Sejajar serat $\left(\mathrm{kg} / \mathrm{cm}^{2}\right)$ & 433 & 22 & 497 & 38 & $0.03 *$ \\
\hline Tekan tegak lurus serat $\left(\mathrm{kg} / \mathrm{cm}^{2}\right)$ & 203 & 18 & 163 & 9 & $0.11 \mathrm{~ns}$ \\
\hline
\end{tabular}

Ket: $\mathrm{MOR}=$ modulus of rupture, $\mathrm{MOE}=$ modulus of elasticity, $*=$ berbeda nyata pada taraf uji $5 \%$, ns $=$ tidak berbeda nyata 

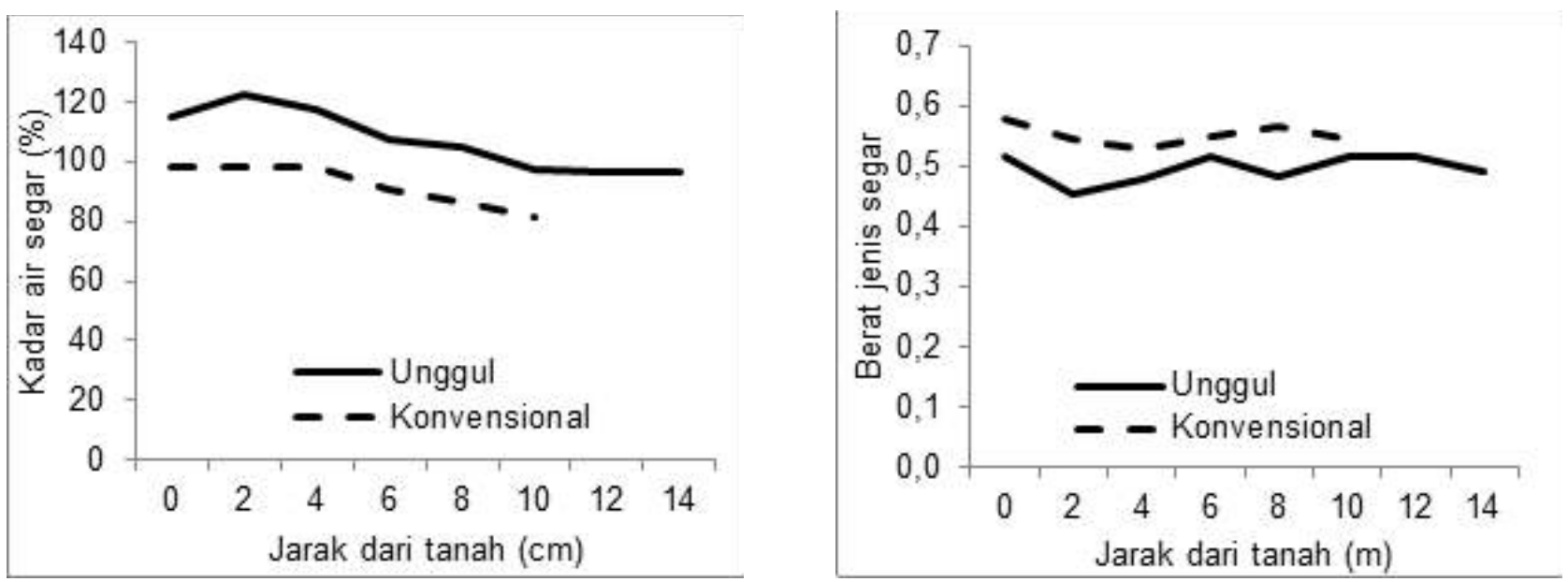

Gambar 1. Variasi aksial kadar air segar dan berat jenis segar kayu jati unggul dan jati konvensional
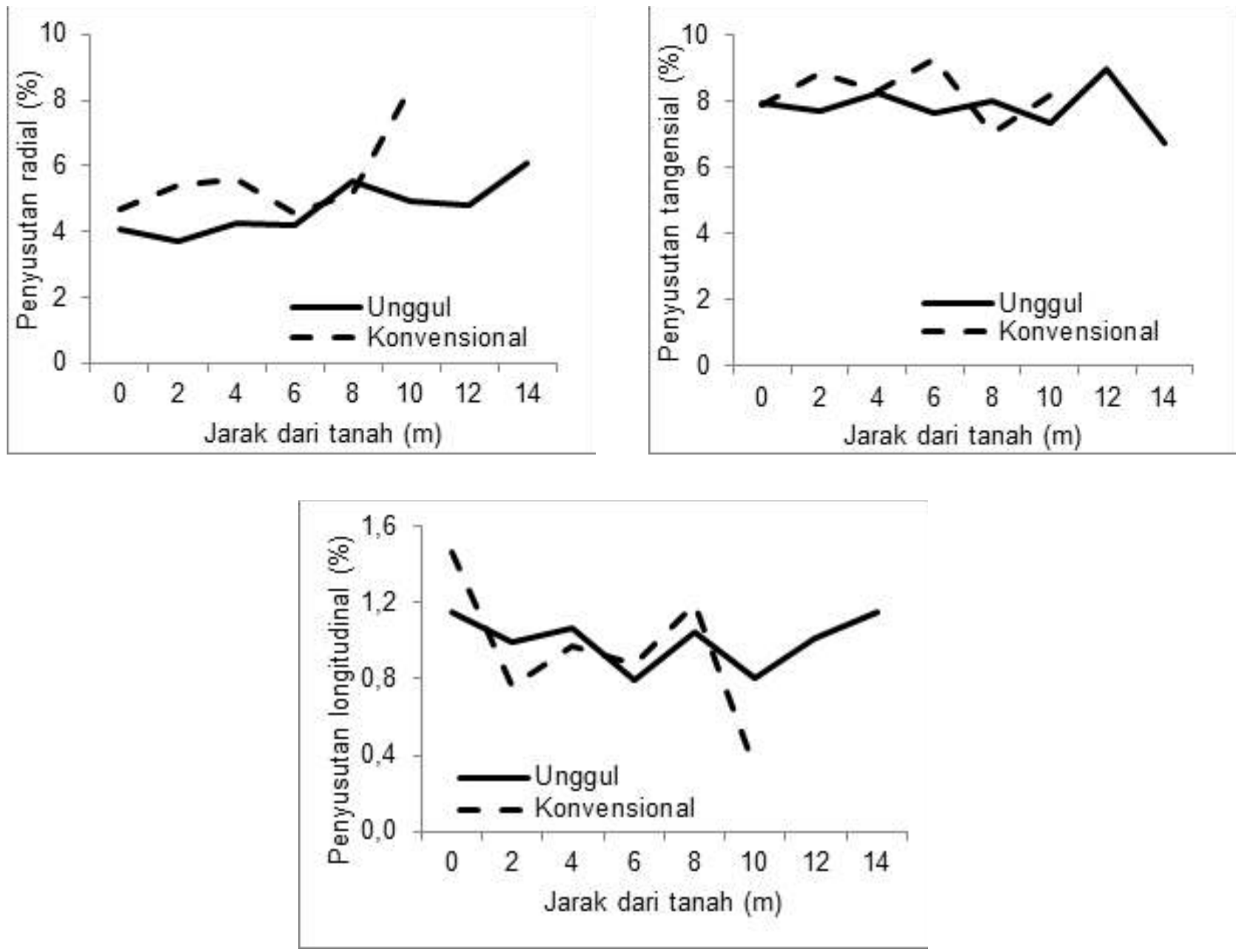

Gambar 2. Variasi aksial penyusutan radial, tangensial, dan longitudinal kayu jati unggul dan konvensional

keteguhan tekan sejajar dan tekan tegak lurus serat juga memiliki pola yang hampir sama yakni agak menurun sampai dengan $2 \mathrm{~m}$ di atas tanah kemudian naik menuju pangkal (Gambar 4). Secara umum diketahui bahwa berat jenis berkorelasi positif terhadap sifat mekanika kayu (Kollman dan Côté, 1984). Berdasarkan hasil tersebut, menunjukkan bahwa kayu jati unggul dan jati konvensional 

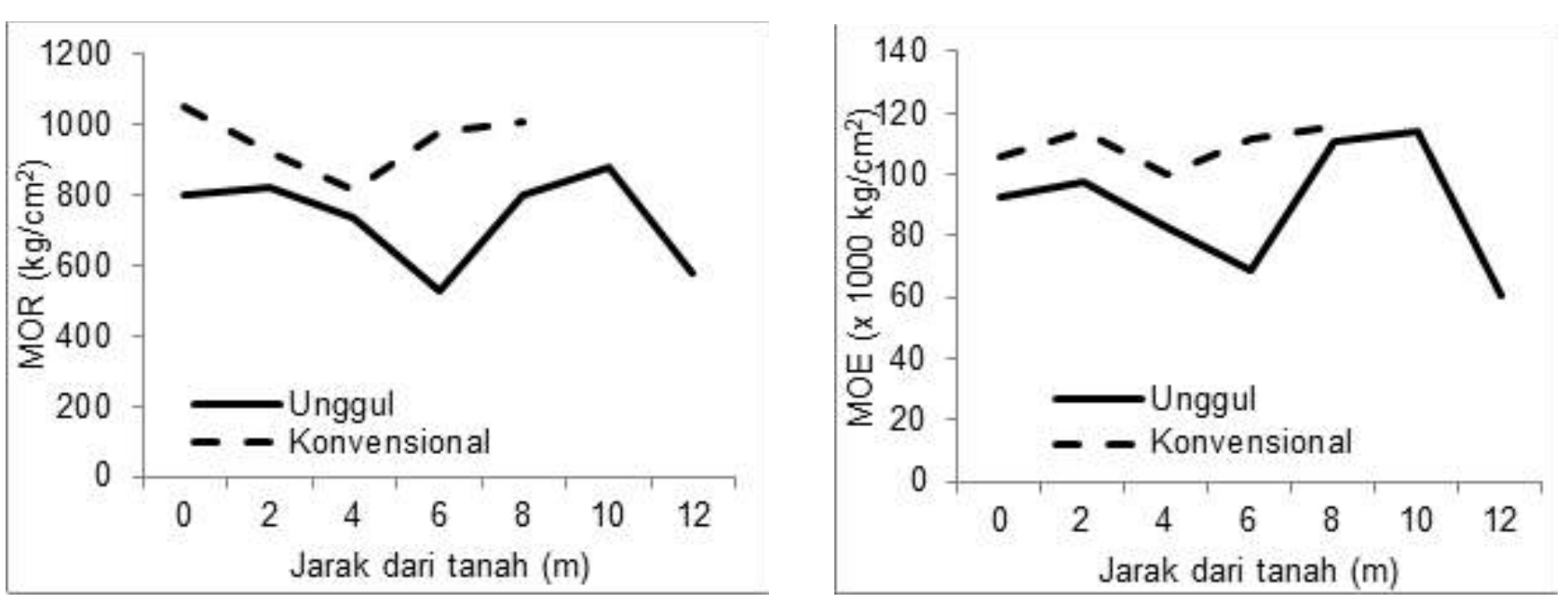

Gambar 3. Variasi aksial MOR dan MOE kayu jati unggul dan konvensional
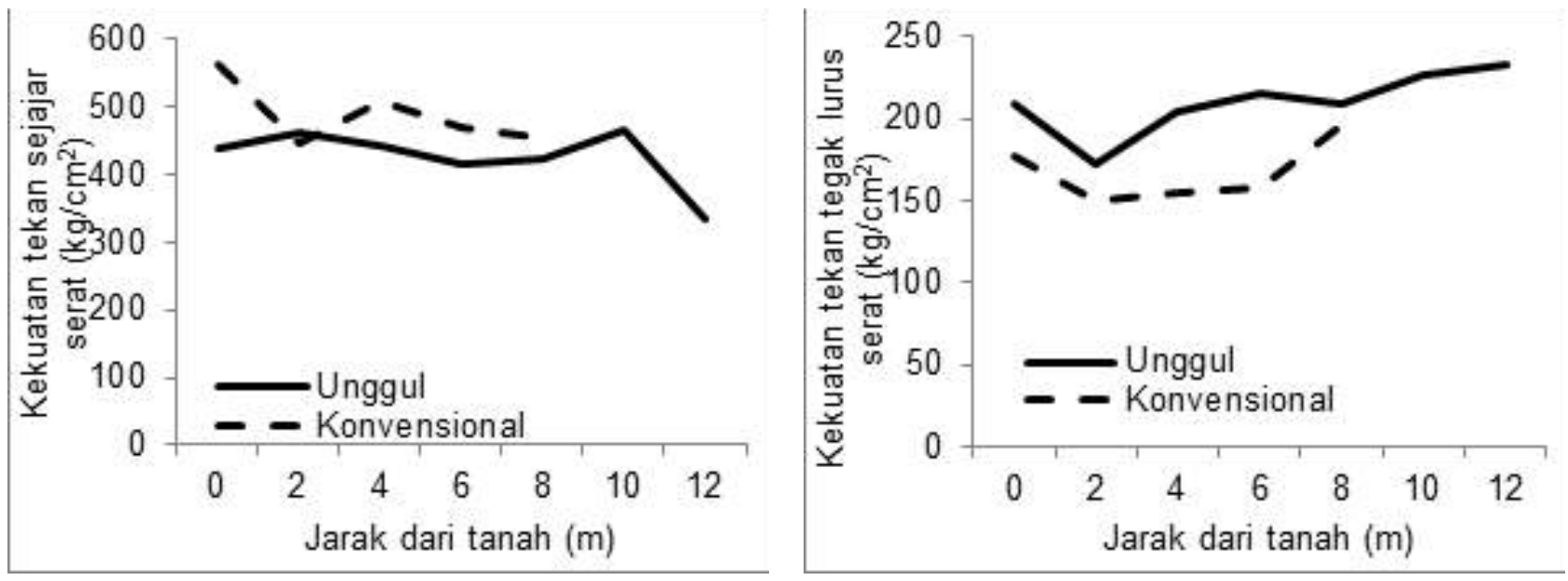

Gambar 4. Variasi aksial keteguhan tekan sejajar dan tegak lurus serat kayu jati unggul dan jati konvensional

memiliki pola variasi aksial sifat fisika dan mekanika yang hampir sama.

\section{KESIMPULAN}

Total 6 pohon digunakan dalam penelitian ini, yang terdiri dari 3 pohon jati unggul "Mega" umur 11 tahun dan 3 pohon jati konvensional umur 14 tahun yang ditanam di Hutan Pendidikan Wanagama, Gunungkidul, Yogyakarta. Penelitian ini bertujuan untuk mengetahui sifat fisika dan mekanika kayu jati unggul serta kayu jati konvensional sehingga diharapkan dapat diperoleh informasi yang lebih lengkap mengenai sifat-sifat kayu jati unggul. Sebagai hasilnya, sifat fisika kayu tidak berbeda nyata antara kayu jati unggul dan kayu jati konvensional, kecuali kadar air segar. Hal ini menunjukkan bahwa kayu jati unggul dan konvensional memiliki sifat fisika yang sama. Sedangkan untuk sifat mekanika kayu, kekuatan lengkung statis (MOR dan MOE) serta kekuatan tekan sejajar serat berbeda nyata antara kayu jati unggul dan jati konvensional. Selanjutnya, kayu jati unggul dan jati konvensional memiliki pola variasi aksial sifat fisika dan mekanika yang hampir sama.

\section{UCAPAN TERIMA KASIH}

Penulis mengucapkan terima kasih kepada Hutan Pendidikan Wanagama, Gunungkidul atas sampel 
pohon yang diberikan. Ucapan terima kasih juga diucapkan kepada Fakultas Kehutanan UGM atas pendanaan (DPP 2015) yang diberikan terhadap penelitian ini.

\section{DAFTAR PUSTAKA}

Anonim. 1957. Standard British 373, 1957. Methods of Testing Small Clear Specimen of Timber, London.

Anonim. 2011. Selected wood properties and potential uses for plantation teak and poumuli. ACIAR project report FST/2007/020. States of Queensland, Dept of Employment, Economic Development and Inovation. 1-35.

Basri E \& Wahyudi I. 2012. Sifat dasar kayu jati plus Perhutani dari berbagai umur dan kaitannya dengan sifat dan kualitas pengeringan. Jurnal Penelitian Hasil Hutan 31, 93-102.

Bhat KM, Priya PB, \& Rugmini P. 2001. Characterization of juvenile wood in teak. Wood Science and Technology 34, 517-532.

Bhat KM \& Priya PB. 2004. Influence of provenance variation on wood properties of teak from the Western Ghat region in India. IAWA Journal 25, 273-282

Bowyer JL, Shmulsky R, \& Haygreen JG. 2003. Forest Products and Wood Science. An Introduction. Iowa State Press. Iowa.

Cordero LDP \& Kanninen M. 2003. Heartwood, sapwood and bark content, and wood dry density of young and mature teak (Tectona grandis) trees grown in Costa Rica. Silva Fennica 37, 45-54

Hidayati F, Ishiguri F, Iizuka K, Makino K, Marsoem SN, Yokota S. 2014. Among-clone variations of anatomical characteristics and wood properties in Tectona grandis planted in Indonesia. Wood and Fiber Science 46, 385-393.

Hidayati $\mathrm{H}$, Ishiguri $\mathrm{F}$, Iizuka $\mathrm{K}$, Makino $\mathrm{K}$, Takashima Y, Danarto S, Winarni WW, Irawati D, Na`iem M, \& Yokota S. 2013a. Variation in tree growth characteristics, stress-wave velocity, and Pilodyn penetration of 24-year-old teak (Tectona grandis) trees originating in 21 seed provenances planted in Indonesia. Journal of Wood Science 59, 512-516.

Hidayati H, Ishiguri F, Iizuka K, Makino K, Tanabe J, Marsoem SN, Na`iem M, Yokota S, \& Yoshizawa N. 2013b. Growth characteristics, stress-wave velocity, and Pilodyn penetration of 15 clones of 12-year-old Tectona grandis trees planted at two different sites in Indonesia. Journal of Wood Science 59, 249-254.

Hidayati F \& Marsoem SN. 2010. Anatomi dan Sifat Fisika Kayu Jati Unggul (Tectona grandis L.f.) Umur 5 Tahun yang Tumbuh di Gunung Kidul pada Berbagai Laju Pertumbuhan. Thesis (Tidak Dipubikasikan). Fakultas Kehutanan. Universitas Gadjah Mada.

Indira EP \& Bhat KM. 1998. Effects of site and place of origin on wood density of teak (Tectona grandis) clones. Journal of Tropical Forest Science 10, 537-541.

Kedharnath S, Chacko VJ, Gupta SK, \& Mattews JD. 1963. Geographic and individual tree variation in some wood character of teak (Tectona grandis L.f): I. Fiber length. Silvae Genetica 12, 181-187

Kollman FFP \& Cote WA. 1984. Principle of Wood Science and Tehnology. Vol I: Solid wood. Springer. Berlin.

Krisdianto \& Sumarni G. 2006. Perbandingan persentase volume teras kayu jati cepat tumbuh dan konvensional umur 7 tahun asal Penajam, Kalimantan Timur. Jurnal Penelitian Hasil Hutan 24, 385-394.

Mawardi P. 2012. Kaya dari Investasi Jati Barokah. PT Agro Media Pustaka, Jakarta.

Moya R \& Marin JD. 2011. Grouping of Tectona grandis (L.f) clones using wood color and stiffness. New Forests 42, 329-345.

Na'iem M. 2000. Early performance of clonal tests of teak. Dalam : Proceedings of Third Regional Seminar on Teak. Potential and opportunities in marketing and trade of plantation teak: Challenge for the new millenium. Hardiyanto EB (Ed.). Fakultas Kehutanan. 271-275.

Perum Perhutani. 2012. Pemantapan Prospek Bisnis Menuju Perhutani Ekselen. Laporan Tahunan. Perum Perhutani. Jakarta.

Putro AM \& Sutjipto AH. 1989. Pengaruh Umur dan Posisi Aksial terhadap Sifat Fisika dan Mekanika Kayu Jati Penjarangan. Skripsi (Tidak Dipubikasikan). Fakultas Kehutanan. Universitas Gadjah Mada. Yogyakarta.

Rodha JM, Cedene P, Guizol P, Santoso L, \& Fauzan AU. 2007. Atlas Industri Mebel Kayu di Jepara. CIFOR. Bogor.

Sulistyo J \& Marsoem SN. 1995. Pengaruh Umur terhadap Sifat Fisika dan Mekanika Kayu Jati (Tectona grandis L.f). Skripsi (Tidak 
Dipubikasikan). Fakultas Kehutanan. Universitas Gadjah Mada. Yogyakarta.

Suwarno A, Marsoem SN, \& Sutapa JPG. 2000. Variasi Aksial dan Radial Sifat Fisika dan Mekanika Kayu Jati dari Paliyan Gunung Kidul. Skripsi (Tidak Dipubikasikan). Fakultas Kehutanan. Universitas Gadjah Mada. Yogyakarta.

Wahyudi I \& Arifien AF. 2005. Perbandingan struktur anatomis, sifat fisis, dan sifat mekanis kayu jati unggul dan kayu jati konvensional. Jurnal Ilmu \& Teknologi Kayu Tropis 3, 9-15.

Wahyudi I, Priadi T, \& Rahayu IS. 2014a. Karakteristik dan sifat-sifat dasar kayu jati unggul umur 4 dan 5 tahun asal Jawa Barat. Jurnal Ilmu Pertanian Indonesia 19, 50-56.

Wahyudi I, Sinaga DKD, Muhran, \& Jasni LB. 2014b. Pengaruh jarak tanam terhadap pertumbuhan pohon dan beberapa sifat fisis-mekanis kayu jati cepat tumbuh. Jurnal Ilmu Pertanian Indonesia 19, 204-210.

Wanneng PX, Ozarska B, \& Daian MS. 2014. Physical properties of Tectona grandis grown in Laos. Journal of Tropical Forest Science 26, 389-396.

Wardani BE, Na'iem M, \& Indrioko S. 2008. Evaluasi uji klon jati (Tectona grandis L.f.) umur 9 tahun di KPH Ciamis dan KPH Cepu Perum Perhutani. Thesis (Tidak Dipubikasikan). Fakultas Kehutanan. Universitas Gadjah Mada. 